\title{
Is there a role for inherited TR $\beta$ mutation in human carcinogenesis?
}

\author{
Qual o papel da mutação do TR $\beta$ na \\ carcinogênese da tireoide em humanos?
}

Letícia Schwerz Weinert', Lucieli Ceolin', Mírian Romitti', Eduardo Guimarães Camargo' , Ana Luiza Maia'

\section{SUMMARY}

Resistance to thyroid hormone (RTH) is a rare autosomal dominant inherited disorder characterized by end-organ reduced sensitivity to thyroid hormone. This syndrome is caused by mutations of the thyroid hormone receptor (TR) $\beta$ gene, and its clinical presentation is quite variable. Goiter is reported to be the most common finding. A close association of TR $\beta$ mutations with human cancers has become apparent, but the role of TR $\beta$ mutants in the carcinogenesis is still undefined. Moreover, higherTSH levels, described in RTH syndrome, are correlated with increased risk of thyroid malignancy, whereas TSH receptor stimulation is likely to be involved in tumor progression. We report here an illustrative case of a 29 year-old patient with RTH caused by a mutation in exon 9 (A317T) of TR $\beta$ gene, who presented multicentric papillary thyroid cancer. We review the literature on this uncommon feature, and discuss the potential role of this mutation on human tumorigenesis, as well as the challenges in patient follow-up. Arq Bras Endocrinol Metab. 2012;56(1):67-71

\section{SUMÁRIO}

A síndrome da resistência aos hormônios tireoidianos (RHT) é caracterizada por redução da sensibilidade aos hormônios da tireoide. A apresentação clínica é variável, sendo a presença de bócio a manifestação mais frequentemente descrita. A associação de mutação no receptor $\beta$ e neoplasias em humanos vem sendo demonstrada recentemente, porém o mecanismo pelo qual a mutação desse receptor está envolvida na carcinogênese não está completamente definido. Além disso, níveis elevados de TSH sérico, descritos na RHT, estão associados a aumento do risco de câncer de tireoide, e o estímulo do TSH está provavelmente envolvido na patogênese desses carcinomas. Este artigo relata o caso de um homem de 29 anos com RHT, com análise molecular demonstrando mutação no éxon 9 , códon 317 , e carcinoma papilar de tireoide. Revisamos a literatura dos casos relatados os quais descrevem associação entre RHT e câncer de tireoide e discutimos os desafios do tratamento e seguimento desses pacientes. Arq Bras Endocrinol Metab. 2012;56(1):67-71

\author{
Thyroid Section, Endocrine \\ Division, Hospital de \\ Clínicas de Porto Alegre, \\ Porto Alegre, RS, Brazil
}

\author{
Correspondence to: \\ Ana Luiza Maia \\ Serviço de Endocrinologia, \\ Hospital de Clínicas de Porto \\ Alegre \\ Rua Ramiro Barcelos, 2.350 \\ prédio $12,4^{\circ}$ andar \\ 90035-052 - Porto Alegre, \\ RS, Brazil \\ almaia@ufrgs.br
}

Received on 7/Aug/2011 Accepted on 20/Jan/2012

\section{INTRODUCTION}

$\mathrm{R}^{\mathrm{c}}$ esistance to thyroid hormone (RTH) is a rare autosomal dominant inherited disorder characterized by end-organ reduced sensitivity to thyroid hormone. Although many steps are required for thyroid hormone to exert its action on target tissues, the first recognized and most common defect involves mutations in the beta-isoform of the thyroid hormone receptor $(\operatorname{TR} \beta)$ gene. The exact incidence of RTH is unknown, because the condition may not be detected by routine screening for hypothyroidism. It is estimated to occur in approximately 1 per 40,000 newborns, and more than 1,000 affected subjects from 339 independent families have already been reported (1). 
The clinical manifestations of RTH are extremely variable, the majority of patients being completely asymptomatic.The finding of elevated serum T4 levels, usually accompanied by high serum levels of T3, associated with non-suppressed serum TSH suggests the diagnosis. The majority of subjects are clinically euthyroid, but symptoms may vary not only among individuals, but also in different tissues of the same patient (1). As a consequence, clinical evidence of thyroid hormone $(\mathrm{TH})$ deficiency and excess often coexist. Serum thyroglobulin concentration tends to be high, reflecting the level of TSH-induced thyroid gland hyperactivity (1). Mutational analysis of the thyroid hormone receptor beta gene (TR $\beta)$ allows the definitive diagnosis of RTH, enables family screening, and may help preventing potential misdiagnosis and inappropriate treatment.

Several experimental studies have demonstrated a role of TR $\beta$ mutation in carcinogenesis, and an association between TR $\beta$ mutations and several human cancers has become increasingly apparent $(2-5)$. The mechanism by which TR $\beta$ mutants are involved in the carcinogenesis has not yet been defined, but it is likely to involve the TSH receptor. Indeed, a high frequency of TR mutations has been reported in human tumors (2). Higher serum TSH levels, typically described in $\mathrm{RTH}$, are associated with increased risk of thyroid malignancy (6) whereas very low TSH levels or suppression are recommended as adjunctive treatment in differentiated thyroid cancer (7).

Here, we report a rare case of RTH and papillary thyroid carcinoma (PTC) in a 29 year-old man presenting a $\operatorname{TR} \beta$ mutation. We review the literature on this uncommon feature, and discuss the potential role of this mutation in human tumorigenesis, as well as the challenges to patient follow-up, particularly the difficulty in achieving adequate serum TSH levels.

\section{CASE REPORT}

A 29 year-old man was referred to our Institution (Hospital de Clínicas de Porto Alegre, Porto Alegre, RS, Brazil) for evaluation of a thyroid nodule and molecular diagnosis of RTH, diagnosed at 15 years of age, based on elevated serum thyroid hormone, normal TSH levels and positive family history. Laboratory evaluation at diagnosis was as follows: serum TSH $3.68 \mu \mathrm{UI} / \mathrm{mL}$ (reference range $0.27-4.2$ ), and total $\mathrm{T} 4>24 \mu \mathrm{g} /$ $\mathrm{dL}$ (reference range $5.1-14.1 \mu \mathrm{g} / \mathrm{dL}$ ). At our insti- tution, thyroid function revealed TSH $7.45 \mu \mathrm{UI} / \mathrm{mL}$, free T4 $3.07 \mu \mathrm{g} / \mathrm{dL}(0.93-1.7 \mu \mathrm{g} / \mathrm{dL})$, T3 $226 \mathrm{ng} /$ $\mathrm{dL}(80-200 \mathrm{ng} / \mathrm{dL})$, thyroid peroxidase antibody 400 $\mathrm{UI} / \mathrm{mL}$. Past medical history included atrial fibrillation with a high ventricular frequency rate, optic nerve atrophy, lactose intolerance, gastroesophageal reflux, and neurosensory deafness. Psychomotor development was considered normal. The patient's father had a history of thyroid nodule, total thyroidectomy, and cardiac death around 45 years of age. His 32 year-old brother has also been diagnosed with RTH and underwent total thyroidectomy due to a thyroid nodule, later diagnosed as thyroid hyperplasia in the anatomopathological examination, was also obese, schizophrenic, and had dyslipidemia.

Physical examination revealed blood pressure of $120 / 78 \mathrm{mmHg}$ and heart rate of 56 beats per minute. His height and weight were $1.69 \mathrm{~m}$ and $69 \mathrm{~kg}$, respectively, and his body mass index was $24.15 \mathrm{~kg} / \mathrm{m}^{2}$. Cervical examination revealed a palpable and not enlarged thyroid, with a palpable hard nodule. A remarkable finding was gaze-evoked nystagmus with fixation. Cervical ultrasonography (US) showed two solid nodules $(1.4 \mathrm{~cm}$ and $1.6 \times 1.2 \mathrm{~cm})$ in the right thyroid lobe, the larger one with microcalcifications and intense central blood flow. US also detected two additional smaller nodules in the right and left lobe, measuring 1.1 and 1.0 $\mathrm{cm}$ in diameter, respectively. Total thyroid volume was $21.5 \mathrm{~cm}^{3}$.

Total thyroidectomy was indicated after two unsatisfactory fine-needle aspiration biopsies. Intraoperative frozen-section analysis showed PTC and bilateral cervical lymph node dissection was performed. Histopathological examination revealed multicentric PTC without metastasis in 11 lymph nodes examined.

The molecular sequence analysis of the TR $\beta$ gene revealed the missense mutation GCT $\rightarrow$ ACT, in exon 9 (codon 317), causing the change of the amino acid alanine to threonine (A317T). Molecular analysis of the patient's brother revealed the same mutation.

Radioactive iodine (100 mci) was administered and ${ }^{131}$ I whole-body scan uptake was detected only in the neck bed. After surgery, treatment with $200 \mu \mathrm{g}$ /day of levothyroxine was started. Thirty days later, the patient became clinically hypothyroid, and laboratory analysis showed TSH $73.68 \mu \mathrm{UI} / \mathrm{mL}$, total T4 $19 \mu \mathrm{g} / \mathrm{dL}$, free T4 $3.5 \mathrm{ng} / \mathrm{dL}$, and T3 $133 \mathrm{ng} / \mathrm{dL}$. Thyroid hormone replacement was increased to $400 \mathrm{mcg} /$ day, and the patient was instructed to avoid lactose-rich food in 
order to improve hormone absorption. Hypothyroid symptoms improved, but there was a new episode of atrial fibrillation. The patient's cardiologist decided to change the antiarrhythmic drug sotalol to propafenone. Five months after surgery and radioactive iodine treatment, thyroglobulin evaluation was negative, but anti-thyroglobulin was positive, 1:100. At this moment, TSH was $37.98 \mu \mathrm{UI} / \mathrm{mL}, \mathrm{T} 420.5 \mu \mathrm{g} / \mathrm{dL}$, T4L 3.15 $\mathrm{ng} / \mathrm{dL}$, and T3 $118.27 \mathrm{ng} / \mathrm{dL}$. T3 replacement was initiated at $20 \mathrm{mcg}$ every other day and three months later, TSH was $1.15 \mu \mathrm{UI} / \mathrm{mL}$, T4 $26.4 \mu \mathrm{g} / \mathrm{dL}$, T4L $4.85 \mathrm{ng} / \mathrm{dL}$, and T3 $208.53 \mathrm{ng} / \mathrm{dL}$. Reevaluation one year after surgery revealed similar laboratory findings, and cervical US did not show abnormalities.

\section{METHODS}

\section{Laboratory investigation}

Serum TSH, total T4, or free T4 and T3 were measured using ECLIA (Roche). Thyroid peroxidase antibody was determined by chemiluminescence (Siemens, Immulite 2000).

\section{Molecular analysis}

Genomic DNA was prepared from peripheral blood leukocytes by standard procedures. The TR $\beta$ gene was amplified using PCR (polymerase chain reaction) with specific primers for exon 9 (forward 5'-AGTGAATTCACAGAAGGTTATTCCTATTGC-3' and reverse 5'-GATCTGCAGGCTCTTTGGATGCCCACTAAC-3') and exon 10 (forward 5'-AGTCTGCAGAGGCCTGGAATTGGACAAAGC-3' and reverse 5'-GGAATTATGAGAATGAATTCAGTCAGT-3'). Cycling conditions were as follows: initial denaturation $\left(94^{\circ} \mathrm{C}\right.$, $5 \mathrm{~min}$ ) and then 35 cycles (denaturation, $94^{\circ} \mathrm{C}$ for $30 \mathrm{~s}$; annealing, $54^{\circ} \mathrm{C}$ for $30 \mathrm{~s}$; synthesis, $72^{\circ} \mathrm{C}$ for $1 \mathrm{~min}$ ), followed by a final extension of $5 \mathrm{~min}$ at $72^{\circ} \mathrm{C}$.

Genotyping was performed using direct sequencing. For sequencing, PCR products were purified using the GFX PCR DNA purification kit (GE Healthcare, Buckinghamshire, UK), and submitted to direct sequencing using the Big Dye ${ }^{\mathrm{TM}}$ Terminator Cycle Sequencing Ready Reaction Kit (Applied Biosystems, Foster City, CA, USA).

\section{DISCUSSION}

There is no specific clinical manifestation of the RTH syndrome, but goiter is the most common finding, re- ported in $66 \%-95 \%$ of cases $(1,8)$. Other characteristics are short stature, hyperactive behavior, attention disorder, anxiety, low intelligence quotient, and cardiac abnormalities (8-10). The reasons for the different phenotypes associated with the RTH syndrome are not entirely understood. Phenotypic expression may vary in patients with the same genotype $(8,9)$, or even in members of the same family (8). Here, we present a case of a 29-year-old man harboring a mutation in exon 9 , codon 317 , presenting uncommon clinical features, such as optic nerve atrophy, neurosensory hearing loss, lactose intolerance gastroesophageal reflux, and atrial fibrillation. However, the most remarkable finding was the presence of multicentric PTC.

An association between mutations of TR $\beta$ and human cancers has become increasingly apparent since the identification of high frequencies of mutant TRs in several human cancers, including papillary thyroid carcinoma $(3,4)$. However, the role of mutated TR $\beta$ in carcinogenesis is still unclear.

In an animal model of an inherited form of RTH in mice homozygousi for a negative mutant of TR $\beta$ $\left(\mathrm{TR} \beta^{\mathrm{PV}}\right.$, unique mutation at exon 10 , codon 448 ), high levels of serum TSH ( 400 fold) seemed to stimulate the proliferation of thyroid cells. These animals exhibited diffuse adenomatous hyperplasia as early as 3 weeks of age, and developed metastatic thyroid cancer, with both anaplastic and follicular patterns. On the other hand, heterozygous mice (TSH mildly increased, twofold) showed no detectable hyperplasia, suggesting that TSH-mediated hyperplasia could be an initial step in carcinogenesis (5). Gene profile analyses of TR $\beta^{\mathrm{PV}_{-}}$ mutated mice showed that the signaling pathways mediated by TSH, peptide growth factors (IGF-I, EGF, FGF), transforming growth factor- $\beta$ (TGF- $\beta$ ), tumor necrosis factor- $\alpha$ (TNF- $\alpha$ ) and nuclear factor- $\mathrm{k} \beta$ (NF$\mathrm{k} \beta$ ) were activated, whereas pathways mediated by peroxisome proliferator-activated receptor $\gamma(\operatorname{PPAR} \gamma)$ were repressed. This is particularly relevant in view of recent work suggesting that altered PPAR $\gamma$ expression and function could be an important risk factor in the development of human thyroid carcinomas. TR $\beta^{\mathrm{PV}}$ deleterious effects causing thyroid cancer are, therefore, at least in part, mediated by interference with the transcriptional activity of wild-type TR, thereby leading to abnormal repression of tumor suppressors (PPAR $\gamma$ ) (2).

Additional studies using mice with deletion of all functional TRs $[\operatorname{TR} \alpha \mathrm{l}(-/-)$ and $\operatorname{TR} \beta(-/-)]$ have demonstrated that these animals developed follicular 
thyroid carcinoma with pathological progression from hyperplasia to capsular and vascular invasion, anaplasia and metastasis. Molecular analysis revealed that tumor promoters such as the pituitary tumor-transforming gene (PTTG) were activated, and tumor suppressors such as PPAR $\gamma$ and p53 were suppressed during the carcinogenesis process (11). Altogether, mouse models indicate that TR mutations could lead to other abnormalities beyond resistance to $\mathrm{TH}$, including thyroid cancer, and may act as oncogenes. Tumorigenesis mediated by $\mathrm{TR} \beta^{\mathrm{PV}}$ would involve complex alterations of multiple signaling pathways, aberrant transcriptional activity, and derailed post-transcriptional mechanisms (2). However, it is unlikely that mutated $\operatorname{TR} \beta$ acts as an initiator of carcinogenesis. It probably cooperates with other pathways in the transformation of proliferative thyroid cells stimulated by TSH into cancer cells.

In addition to the data obtained from animal studies, clinical studies have demonstrated that the likelihood of thyroid cancer increases with higher serum TSH concentrations, even within normal ranges (6). Higher TSH levels have been associated with an advanced stage of thyroid cancer, whereas a relationship between decreased expression of TSH-R and poor prognostic scores has been demonstrated. Furthermore, overall survival is improved in thyroid cancer patients treated with suppressive doses of levothyroxine (12).

Based on the above considerations, high incidence of thyroid cancer could be expected in patients with RTH. Nevertheless, although goiter is a common finding in RTH, thyroid cancer is not, and few cases have been reported in the literature. In a large series of patients reported by Brucker-Davis and cols., we found the first report on the association between thyroid can- cer and RTH syndrome (8). More recently, four other cases were described (13-16).

Table 1 summarizes the clinical and molecular characteristics of our case and previously reported ones. The series of cases reported by Brucker-Davis and cols. (8) did not describe individual phenotypes, and this limited our conclusions about their patient with RTH and thyroid cancer. All other cases reported the occurrence of differentiated thyroid cancer of the papillary type. A remarkable aspect is that both males and females were affected in a similar frequency. Except for our case, all patients tested for thyroid peroxidase antibody showed to be negative. All reports highlighted the difficulties of managing post-surgical hypothyroidism, and the need for higher than usual doses of levothyroxine $(\sim 3 \mu \mathrm{g} / \mathrm{kg})$ to get near-normal TSH levels $(13,14,16)$. A fascinating observation is that, despite the chronic TSH stimulation characteristic of RTH, disease presentation at diagnosis and follow-up of these patients suggests non-aggressive tumor behavior $(13,14,16)$.

Another interesting aspect of the present case was the uncommon features of RTH syndrome presented by the patient, such as optic nerve atrophy, neurosensory hearing loss, and atrial fibrillation. The assumption that an aberrant thyroid hormone action is involved on the pathogenesis of these abnormalities is supported by interesting animal model studies. It has been shown that thyroid hormone action is required for normal cone opsin expression during mouse retinal development (17), whereas hearing impairment has been described in homozygous mutant mice (18). Moreover, although TR $\beta$-mutant mice showed surprisingly little effect on cardiac function in vivo except for cardiac hypertrophy (19), decreased atrial depolarization velocity has been demonstrated in mutant mice (20).

Table 1. Clinical and molecular characteristics of patients with resistance to thyroid hormone and papillary thyroid carcinoma

\begin{tabular}{|c|c|c|c|c|c|c|c|}
\hline Patient & Sex & $\begin{array}{c}\text { Age } \\
\text { (years) }\end{array}$ & $\begin{array}{l}\text { TR } \beta \text { mutation } \\
\text { (exon/codon) }\end{array}$ & $\begin{array}{l}\text { Tumor size } \\
\text { (cm)* }\end{array}$ & Multicentric & LN Metastasis & Reference \\
\hline 1 & NA & NA & NA & NA & NA & NA & Brucker-Davis and cols., 1995 (8) \\
\hline 2 & $\mathrm{~F}$ & 46 & 10/R429Q & 0.5 & - & - & Taniyama and cols., 2001 (15) \\
\hline 3 & $\mathrm{~F}$ & 26 & NA & NA & NA & NA & Siristatidis and cols., 2004 (16) \\
\hline 4 & $\mathrm{~F}$ & 38 & 9/M310T & 0.4 & + & - & Kim and cols., 2010 (13) \\
\hline 5 & M & 48 & No mutation identified & $N A^{\epsilon}$ & - & - & Paragliola and cols., 2011 (14); Patient 1 \\
\hline 6 & M & 63 & 10/P453Т & 0.6 & - & - & Paragliola and cols., 2011 (14); Patient 2 \\
\hline 7 & M & 29 & 9/A317T & 1.3 & + & - & Weinert, 2011 \\
\hline
\end{tabular}

NA: not available; F: female; M: male; LN: lymph nodes.

* If multicentric, the biggest tumor size is reported; ${ }^{\epsilon} \mathrm{TNM}=\mathrm{pT} 2$. 
In conclusion, the reported case presents an interesting finding of simultaneous $\mathrm{RTH}$ and PTC, and highlights the possible common mechanism for RTH and carcinogenesis. Despite all accumulated data on mutated-TR $\beta$ or TSH mediated-effects on thyroid carcinogenesis, the reviewed cases illustrate the gaps in our understanding of the complex pathways of thyroid hormone action on human neoplasms.

Disclosure: no potential conflict of interest relevant to this article was reported.

\section{REFERENCES}

1. Refetoff S, Dumitrescu AM. Syndromes of reduced sensitivity to thyroid hormone: genetic defects in hormone receptors, cell transporters and deiodination. Best Pract Res Clin Endocrinol Metab. 2007;21(2):277-305.

2. Cheng SY, Leonard JL, Davis PJ. Molecular aspects of thyroid hormone actions. Endocr Rev. 2010;31(2):139-70.

3. Kamiya Y, Puzianowska-Kuznicka M, McPhie P, Nauman J, Cheng SY, Nauman A. Expression of mutant thyroid hormone nuclear receptors is associated with human renal clear cell carcinoma. Carcinogenesis. 2002;23(1):25-33.

4. Puzianowska-Kuznicka M, Krystyniak A, Madej A, Cheng SY, Nauman J. Functionally impaired TR mutants are present in thyroid papillary cancer. J Clin Endocrinol Metab. 2002;87(3):1120-8.

5. Suzuki $H$, Willingham MC, Cheng SY. Mice with a mutation in the thyroid hormone receptor beta gene spontaneously develop thyroid carcinoma: a mouse model of thyroid carcinogenesis. Thyroid. 2002;12(11):963-9.

6. Boelaert K, Horacek J, Holder RL, Watkinson JC, Sheppard MC, Franklyn JA. Serum thyrotropin concentration as a novel predictor of malignancy in thyroid nodules investigated by fine-needle aspiration. J Clin Endocrinol Metab. 2006;91(11):4295-301.

7. Maia AL, Ward LS, Carvalho GA, Graf H, Maciel RM, Maciel LM, et al. [Thyroid nodules and differentiated thyroid cancer: Brazilian consensus]. Arq Bras Endocrinol Metabol. 2007;51(5):867-93.

8. Brucker-Davis F, Skarulis MC, Grace MB, Benichou J, Hauser P, Wiggs $E$, et al. Genetic and clinical features of 42 kindreds with resistance to thyroid hormone. The National Institutes of Health Prospective Study. Ann Intern Med. 1995;123(8):572-83.
9. Adams M, Matthews C, Collingwood TN, Tone $Y$, Beck-Peccoz P, Chatterjee KK. Genetic analysis of 29 kindreds with generalized and pituitary resistance to thyroid hormone. Identification of thirteen novel mutations in the thyroid hormone receptor beta gene. J Clin Invest. 1994;94(2):506-15.

10. Magalhaes PK, Rodrigues Dare GL, Rodrigues Dos Santos S, Nogueira CR, de Castro M, Zanini Maciel LM. Clinical features and genetic analysis of four Brazilian kindreds with resistance to thyroid hormone. Clin Endocrinol (Oxf). 2007;67(5):748-53.

11. Zhu XG, Zhao L, Willingham MC, Cheng SY. Thyroid hormone receptors are tumor suppressors in a mouse model of metastatic follicular thyroid carcinoma. Oncogene. 2010;29(13):1909-19.

12. Jonklaas J, Sarlis NJ, Litofsky D, Ain KB, Bigos ST, Brierley JD, et al. Outcomes of patients with differentiated thyroid carcinoma following initial therapy. Thyroid. 2006;16(12):1229-42.

13. Kim HK, Kim D, Yoo EH, Lee Jl, Jang HW, Tan AH, et al. A case of resistance to thyroid hormone with thyroid cancer. J Korean Med Sci. 2010;25(9):1368-71.

14. Paragliola RM, Lovicu RM, Locantore $\mathrm{P}$, Senes $\mathrm{P}$, Concolino $\mathrm{P}, \mathrm{Ca}$ poluongo $E$, et al. Differentiated thyroid cancer in two patients with resistance to thyroid hormone. Thyroid. 2011;21(7):793-7.

15. Taniyama M, Ishikawa N, Momotani N, Ito K, Ban Y. Toxic multinodular goitre in a patient with generalized resistance to thyroid hormone who harbours the R4290 mutation in the thyroid hormone receptor beta gene. Clin Endocrinol (Oxf). 2001;54(1):121-4.

16. Siristatidis C, Mastorakos G, Vitoratos N, Gregoriou O, lakovidou $H$, Salamalekis $E$, et al. Thyroid hormone resistance and enlargement of the sella turcica during pregnancy. Arch Gynecol Obstet. 2004;269(2):152-5.

17. Pessoa CN, Santiago LA, Santiago DA, Machado DS, Rocha FA, Ventura DF, et al. Thyroid hormone action is required for normal cone opsin expression during mouse retinal development. Invest Ophthalmol Vis Sci. 2008;49(5):2039-45.

18. Griffith AJ, SzymkoYM, Kaneshige M, Quinonez RE, Kaneshige K, Heintz KA, et al. Knock-in mouse model for resistance to thyroid hormone (RTH): an RTH mutation in the thyroid hormone receptor beta gene disrupts cochlear morphogenesis. J Assoc Res Otolaryngol. 2002;3(3):279-88.

19. Ortiga-Carvalho TM, Hashimoto K, Pazos-Moura CC, Geenen D, Cohen R, Lang RM, et al. Thyroid hormone resistance in the heart: role of the thyroid hormone receptor beta isoform. Endocrinology. 2004;145(4):1625-33.

20. Almeida NAS, Cordeiro A, Machado DS, Souza LL, Ortiga-Carvalho TM, Campos-de-Carvalho AC, et al. Connexin40 messenger ribonucleic acid is positively regulated by thyroid hormone (TH) acting in cardiac atria via the TH receptor. Endocrinology. 2009;150:546-54. 